\title{
Bureaucracy that Kills: Federal Sovereign Immunity and the Discretionary Function Exception
}

\author{
WILLIAM G. WEAVER University of Texas at El Paso \\ THOMAS LONGORIA University of Kansas
}

\begin{abstract}
Dolitical scientists normally discuss sovereign immunity in the context of international law and relations. The domestic effects of sovereign immunity are almost never examined, even though those effects are profound and implicate a range of issues of interest to political scientists. The Federal Tort Claims Act (FCTA) (1946) is a main waiver of federal sovereign immunity and is designed to allow people injured by government employees to sue for money damages. The FTCA has a number of exceptions, the most prominent of which is known as the "discretionary function exception." This exception retains sovereign immunity for the United States when a federal employee acts "based upon the exercise or performance or the failure to exercise or perform a discretionary function or duty... whether or not the discretion involved be abused." This simple exception expanded into a comprehensive tool of government that now confounds justice and federal governmental accountability.
\end{abstract}

$\mathbf{O}$ n April 16, 1947, a ship anchored in the harbor of Texas City, the Grandcamp, exploded, leveling most of the city, killing 576 people, and injuring five thousand more. Destined for Europe as part of the Marshall Plan, the Grandcamp had more than 1,850 tons of fertilizer grade ammonium nitrate (FGAN) aboard, along with a heavy load of commercial explosives. When the captain of the Grandcamp saw smoke coming from a hold of the ship, he ordered the hatches battened and injected steam into the cargo area to quell the fire. This was normal procedure for fires in holds, but unfortunately those administering the fertilizer program neglected to warn the captain that FGAN is an oxidizing agent and does not need any external oxygen for combustion. The heat and the pressure created by the spontaneous combustion, the steam, and the battened hold caused the FGAN to explode.

Federally owned munitions factories that less than two years before the disaster had been turning out ordnance to be dropped on Europe now manufactured fertilizer to be spread on its fields. A private company would have been liable for the damage and injury caused by the explosions, but the United States escaped liability through a little-known provision of the Federal Tort Claims Act (FTCA) (1946). The government had the FGAN bagged at extremely high temperatures, usually $200^{\circ} \mathrm{F}$ (Dalehite v. U.S. 1952 [hereafter Dalehite], 40), and administrators knew perfectly well the dangerous propensities of the fertilizer and about incidents of FGAN undergoing spontaneous combustion and exploding (66-7). Even more, there were no warnings on the fertilizer bags, and stevedores, cargo

William G. Weaver is Associate Professor of Political Science, University of Texas at El Paso, El Paso, TX 79968-0547 (wweaver@ utep.edu). Thomas Longoria is Associate Professor of Public Administration, University of Kansas, 1541 Lilac Lane \#318, Lawrence, KS, 66045-3177.

The authors thank Kenneth Meier, Kathleen Staudt, and three anonymous reviewers for their conscientious and thorough reviews of drafts of this article. Though he would no doubt disagree with much that we have said here, we also thank Harold Krent for starting us down the path that led to this result. masters, and ship captains were not informed about the properties of FGAN. Most telling, administrators halted safety testing of the fertilizer when contract laboratories told them that, under procedures adopted by the government, it looked as if the FGAN would pose substantial danger to the public (66).

The Discretionary Function Exception (DFE) (FTCA 1946, sec. 2680(a)) to the FTCA protects the federal government from liability when policy decisions or actions of agencies or employees injure people. Growing out of the doctrines of sovereign immunity and separation of powers, the exception specifically applies "whether or not the discretion involved be abused." In Dalehite, the DFE saw its first use to protect the U.S. Government from liability, and it succeeded magnificently, turning out to be just the beginning in a long train of success. The DFE gives rise to several important and interesting questions concerning its scope and use. But beyond these matters, it provides a concrete example for examining contending understandings of the role of judges in controlling bureaucracy, influencing policy formulation, and bringing administrators to account for their actions.

Debates over judicial control of bureaucracy are contentious and long-standing. In the 1950s and 1960s a small but influential group of scholars sought diverse means to limit administrative discretion and independence. This group included Henry Friendly (1962), Walter Gellhorn and Clark Byse (1974), Louis Jaffe, Kenneth Culp Davis, and others, but Jaffe and Davis are perhaps the most important authors for the present concerns.

In Judicial Control of Administrative Action, Jaffe (1965) presented a powerful view of the relationship between courts and administrators. He reacted against New Deal antijuridical views of public administration theorists, who believed that "if any person is to count for less than one... it is the lawyer" and that the lawyer suffered from a "meager social outlook," representing "everything stultifying" (Waldo 1948, 79). To these New Deal theorists, in administrative agencies "thoroughly motored and controlled by rational elaboration," judicial review and incursion into the sphere of 
the administrator were not only disruptive but also unjust (Jaffe 1973, 1186). Born in this crucible of antilegalism, the DFE first appeared in proposed legislation in 1942 (H.R. 6463), to help prevent what some commentators referred to as judicial "sabotage of the administrative process" (Blachly and Oatman 1946, 213). Testifying concerning this bill, an assistant attorney general asserted that the DFE preserved administrative autonomy to conduct "legally authorized activity" and protected agencies against "alleged abuse of discretionary authority" (U.S. Congress, House 1942, 33). The exception, therefore, is steeped in the counterjuridical impulse of New Deal administrative theory and is a vestige of an exuberant faith in administrative expertise.

Against the New Deal impulse, Jaffe implored judges to take a "hard look" approach to administrative decision-making. In piquant language, he noted that historically judges have been "adept... at removing the hide of an administrative agency" and that the "glint of the scalpel is still detectable behind the voluminous folds of [judges'] robes" (Jaffe 1965, 565). Judicial surgery on administrative agencies is precisely what Jaffe was after, and to achieve this he had to discredit the tendency to deference adopted by judges when reviewing administrative decisions. He saw judicial review of agency action as the necessary moral countervailing force to the scientism of administration theory and stated that "the touchstone of rejecting an administrative decision is the sense of the judge that it is unfair" (Jaffe 1951,1245). And he termed the New Deal sentiment that agencies should be free of judicial "sabotage" a "heresy" (1259).

Davis likewise authored powerful tracts arguing for control of administrative power, but he focused more narrowly than Jaffe on the mechanics of discretion and disfavored the cumbersome, formalized process of court review of administrative action. Davis (1969, v) saw that injustice at the hands of administrators is directly proportional to the amount of discretion floating free in agencies. He believed that earlier efforts to eliminate or severely constrict administrative discretion actually achieved the opposite result (27-51) and that courts should not try to control discretion directly, but to channel legislators and administrators into avenues of effective rulemaking (220-1). Judicial review in America is too geared to large interests, and the transaction costs of going to court mean that "the system frequently fails to take care of parties with small interests" (155). By "parties with small interests," Davis meant poor, helpless, and troubled people. With appropriate planning and distribution of discretion, these are precisely the sorts of interests that administrators are most effective at serving. The problem, Davis said, is not so much providing substantial discretion to administrators, but how intelligently to circumscribe discretionary power and make sure only the optimal amount of discretion for performance of mandated functions is in the hands of agencies. Our system, Davis said, is in "imbalance"; it is "saturated with excessive discretionary power which needs to be confined, structured, and checked" (27).
More recently, some theorists have gone further than Davis, keeping the opposition to New Deal administrative theory, but embracing New Deal antilegalism in formulating solutions to problems of agency control. These thinkers believe that oversight of administrators need not come from courts; "judicial participation in the administrative process is not indispensable" (Krent 1997, 1187), and though the impulse to "exercise review over discretionary administrative action is understandable, the consequences can be perverse" (1189). But the DFE often arises when administrative incentives are at their worst. Because it provides a shield not only from liability, but also often from discovery, there is an incentive to employ the exception to avoid embarrassment and disclosure of information that would trigger action adverse to agency interests. The DFE is at odds with the work of both Jaffe and Davis, for it frequently protects administrators and their agencies when they wield their discretion most unwisely or even maliciously.

The FTCA can be a powerful tool for controlling agency discretion. As Rosenbloom (2001) notes, it is one of several steps taken by Congress in 1946 to redefine the relationship among Congress, the judiciary, and the bureaucracy in the postwar era. This "legislativecentered" view of public administration acknowledges that administration has legislative functions, that agencies serve as extensions of Congress, that administration should be informed by political authority, and that Congress has oversight and supervisory roles. This view also acknowledges not only that the president and political appointees are charged with day-to-day implementation of statutorily authorized functions, but also that administrators have discretion to formulate action where Congress has not provided explicit direction (Rosenbloom 2001, 776). Significant in Rosenbloom's perspective is that Congress, at a time when it attempted to reclaim control over the bureaucracy, sought to transfer responsibility for determining governmental liability to the judiciary. Rosenbloom (2001, 776), from a largely normative position, argues that it is the primary role of the federal courts to "provide judicial review of agency actions" to prevent the exercise of discretion Congress intended to prohibit. On this view, the FTCA not only transferred determination of federal governmental tort liability to the judiciary, but also sought to make the judiciary partners with Congress in oversight of administrative action.

As discussed more thoroughly below, one of the reasons Congress moved to abandon the private bill system is that it was inefficient. It is generally unwise, though, to rely on federal courts to resolve disputes between citizens and government effectively, and it may not be reasonable in light of weaknesses identified in the judicial branch in areas of policymaking. Effective policymaking requires capacities such as technical expertise and the ability to conduct long-range planning and public policy analysis that facilitate effective implementation, capacities that courts do not possess (Rosenberg 1991, 20). As Rosenberg observes, the efficacy of judicial action is questioned even in areas normally thought to be exemplary instances of the federal courts as effective promoters of social and policy change: 
areas such as civil rights, voting rights, and women's rights (20).

Rosenberg's "constrained court" perspective is well supported by evidence and forces a balanced approach to understanding the policymaking role of federal courts vis-à-vis other branches of government. However, in the case of the DFE, the issue is not about whether judges can effect broad social change by taking on roles as policymakers. In cases where the DFE is raised, the courts are playing a role that they are accustomed to and very well equipped to fulfill. The claims are taken to the courts on relatively narrow legal grounds, the decisions rendered by the courts do not require ongoing enforcement and oversight, and such decisions do not directly alter agency policy and practice. And while the speed, efficiency, and narrow focus of court action are ongoing concerns, suits under the FTCA are usually the only remedy available to citizens harmed by the government.

The DFE is at war with justice, and the question is who should be in the fight. Although judicial control of bureaucracy presents many intractable problems and dangers, we believe that the courts should construe the DFE narrowly, far more narrowly than at present, to maximize judicial review of administrative action. We argue this for several reasons. First, the FTCA substantially commits oversight of administrative action for injuries caused to citizens to the judiciary. Second, when the DFE is raised it is often in cases where great harms have been committed and administrators are trying to avoid embarrassment or disclosure of revealing information about policies and procedures. In such cases, oversight cannot be left to the agencies, and it is dubious to depend on congressional intervention. Third, by their very nature, FTCA cases concern injuries inflicted on citizens at the hands of government. Determination of legal liability for tortious conduct is one of the most common and routinized activities in the legal system, and courts are extremely adept at adjudicating such cases. Here the courts are on sure footing compared to that in administrative oversight cases arising under other statutes that entangle the judiciary more deeply in agency action. Fourth, finding liability under the FTCA is not a direct review of agency policy and practice; no court tells an agency to change a policy or procedure or adopt new standards. When the court finds liability, it, at worst, forces the offending agency administrators to make a calculation of whether to maintain the policy or action that caused the injuries or to make changes. This decision is left to the agency and not the court. Finally, we note that FTCA cases are generally "large interest," rather than Davis's "small interest," cases and, therefore, presumably more amenable to legal resolution.

The DFE is an anachronism sandwiched into an ideal. On the one hand, the FTCA represents a landmark in governmental acceptance of responsibility and efforts to reduce injustice. On the other hand, the DFE and other exceptions to liability in the FTCA are vestiges of an age of credulous faith in the expert administrator. Congress passed the FTCA on the cusp between two eras, between the twilight of New Deal faith in the expert agency and the bare beginnings of an era of profound distrust of administrative discretion; the FTCA reflects both of these eras.

It is also important to know if the DFE is having a substantial effect on our constitutional system and on means of governmental accountability. Although broadened by the FTCA, the exception performs a crucial function in our constitutional system and has long been held by federal courts to be implied in the Constitution. As Justice Marshall observed in Marbury v. Madison $(1803,170)$, "The province of the court is, solely, to decide on the rights of individuals, not to enquire how the executive, or executive officers, perform duties in which they have a discretion."

Where the DFE applies, there is no remedy for governmental abuse, regardless of its seriousness. Indeed, the greater the injury inflicted by the government, the more likely the DFE will be proffered to the courts to immunize agencies, employees, and the United States from liability (Axelrad 2000). To give some idea of the breadth of the DFE, it immunizes the government for the following.

- Allegedly hiding knowledge of a murder by an inmate, securing the inmate's release, and then misleading state law enforcement authorities as he kills five additional people (Taitt v. U.S. 1983).

- Placing a known embezzler in the Witness Protection Program and allowing him to become CEO of a publicly held company, even though he is currently under investigation for defrauding another publicly held company. He steals $\$ 1.5$ million (Jet Industries, Inc. v. U.S. 1984).

- The CIA setting up a dummy investment corporation, placing a known swindler in charge of the organization who then, with government knowledge, bilks private investors out of millions of dollars (Frigard $\mathrm{v}$. U.S. 1988).

- The exposure of military and civilian personnel to pesticides, botulinum toxin, and unapproved vaccines without their knowledge, causing birth defects in children born to exposed parents (Minns v. U.S. 1997).

- Knowingly exposing thousands of employees, military personnel, and private citizens to ionizing radiation, failing to inform or warn the victims of their exposure, and using them as "guinea pigs" in long range studies of the effects of radiation exposure (Allen v. U.S. 1987; Consolidated Atmospheric Testing, in re 1987).

- Conducting a simulated biological attack on an unwarned, unsuspecting San Francisco public utilizing bacteria that causes death and injury (Nevin v. U.S. 1983).

- Cremation and acid reduction of stolen bodies or body parts for radiation assay and study without the permission or knowledge of relatives. ${ }^{1}$

\footnotetext{
${ }^{1}$ Project Sunshine, initiated at a 1953 Atomic Energy Commission conference (see, e.g., Atomic Energy Commission 1953 and Rand Corporation 1953) and lasting until 1985, took parts from cadavers and whole bodies without the permission of relatives (see the Atomic Energy Commission's [1955, 8] discussion of the importance of "body
} 
The list could go on at quite some length. Despite its consequences, the DFE is unaccountably ignored by political scientists and is mentioned only occasionally, usually in connection with international law and the Foreign Sovereign Immunities Act (Evans 1980, 951; Falk 1965, 778; Leigh 1987, 949; Semmelman 1993, 2902 ). This is odd, since many issues central to political science are implicated by the DFE: issues concerning judicial oversight of administrative decisions, separation of powers, governmental accountability, intrusion into the peace and dignity of citizens, and justice. To start out, it will be helpful to sketch a history of sovereign immunity as it relates to our analysis.

\section{FROM "THE KING CAN DO NO WRONG" TO "THE ADMINISTRATOR CAN DO NO WRONG"}

Historically, tyrannies and democracies alike frequently refused to be legally accountable for the wrongs committed by their officials. But governmental immunity from legal action in a democracy, where the people are sovereign, presents special problems. In the United States, efforts to address these problems began in the first Congress. In discussing whether a comptroller of accounts should be empowered to hear and "adjust" claims against the United States, James Madison thought that people turned down by the comptroller should have a "right to petition the Supreme Court for redress, and they should be empowered to do right therein; this will enable [them] to carry [their] claim before an independent tribunal" (Debates and Proceedings in the Congress of the United States, 1, [1965], 612).

Sovereign immunity is one of the few areas of law that remains undisturbed in a slumber of pre-Revolutionary War theory. It is as absolute today in the United States as it was in the England of George III, though the justifications for it have changed. The King and Queen were ultra vires, extrajudicial, and so could not be sued without their consent. Blackstone made this point succinctly in his well-known statement: "[B]esides the attribute of sovereignty the law also ascribes to the king, in his political capacity, absolute perfection. The king can do no wrong" (Ehrlich 1959, 67). And as Pollock and Maitland ([1895] 1968, 516) observe, "If Henry III had been capable of being sued, he would have passed his life as a defendant." Sovereign immunity extended to government officials, and discretionary acts by administrators in conformance with the Crown's desires or policies have always been protected. This extension of immunity to the discretionary functions of administrators acting within the scope and authorization of their duties served several important purposes.

First, it prevented elliptical attacks on the Crown's policies and desires by protecting those charged with

snatching"). Some 15 thousand bodies were mutilated or stolen under this program (Philadelphia Enquirer 1995; Welsome 1998, 299-304). Though, amazingly, apparently no suits were filed over Project Sunshine activities, it seems likely that the government would raise the DFE as a defense in such an event. their execution. A wronged or injured subject might sue the administrator who caused the injury, but courts would suspend judgment unless the King or Queen specifically disclaimed the act of the administrator. If the Crown claimed the act as its own, the administrator was absolutely immune from legal action. By the time of James I, efforts to close off access to legal redress for injured subjects increased. For example, the prefatory statement to a 1609 statute designed to discourage suits against officers begins with the observation that "many causeless and contentious suits ... have been and daily are commenced [by] evil-disposed, contentious persons ... [and these suits are a] hindrance to efficient administration" (Jaffe 1963, 10).

Second, if administrators, or those being recruited for administrative positions, know that their decisions will not place them at peril in suit, they are more likely to accept government employment and to discharge their duties more effectively. Administrators left unprotected may make decisions based on their own perceived risks, rather than in accord with their defined duties.

Finally, the extension of sovereign immunity to the actions of administrators safeguards the public treasury from predation by means of damage awards. As bureaucracy expanded with the reach of the British Empire, so too did the number and severity of injuries caused by governmental policies. Without immunity, government and its administrators would have been subject to enormous damages.

Nevertheless, a number of practices arose that allowed suit both against the King or Queen eo nomine and against the Crown's officers. Beginning as early as the reign of Edward I, the Crown made itself amenable to suit in many circumstances (Jaffe 1963,3). The King and Queen, though, usually retained their immunity from liability for the delicts of their servants, and public administrators were not vicariously liable for the actions of their employees. This doctrine is reaffirmed time and again throughout English history, and a major effort to overthrow it failed in 1865 (Feather v. Queen). The effect of these rules was to secure administrators and policies from judicial oversight and intrusion.

This view of sovereignty and the grant of immunity to administrators leaped the Atlantic and set up firmly in U.S. law. In the United States, with the framing of the Constitution an effort ensued to define the U.S. Government clearly as a robust, unitary sovereign. Hamilton, for example, in Federalist 81, wrote that "it is inherent in the nature of sovereignty not to be amenable to the suit of an individual without its consent" (Madison, James, Alexander Hamilton, and John Jay [1788] 1961, 487). And Chisholm v. Georgia (1793), Cohens v. Virginia (1821), McCulloch v. Maryland (1819), and other cases pressed this issue, with greater or lesser success. As John P. Roche (1961, 801) famously noted, increasing the power of the sovereign was eminently practical under the circumstances of the founding: "In politics there are no immaculate conceptions, and... our very survival in the Hobbesian jungle of world politics depended upon a reordering and strengthening of our natural sovereignty." 
Though present from the Founding, the U.S. Supreme Court explicitly embraced the doctrine of sovereign immunity in 1821 , when it noted that "[i]t is an axiom in politics, that a sovereign and independent State is not liable to the suit of any individual" (Cohens v. Virginia 1821). And in 1907, Justice Holmes gave a famous and succinct, if unsatisfactory, logical justification for sovereign immunity: "[O]n ... logical and practical ground $[\mathrm{s}]$... there can be no legal right as against the authority that makes the law on which the right depends" (Kawananakoa v. Polyblank 1907, 353). But from the beginning, the Republic shifted with discomfort over the consequences sovereign immunity and unchecked administrative discretion could bring down on its citizens. In Poindexter v. Greenhow (1885, 291), Justice Matthews, writing for the Court, lamented,

Of what avail are written constitutions whose bills of right for the security of individual liberty have been written, too often, with the blood of martyrs shed upon the battle-field and the scaffold, if their limitations and restraints upon power may be overpassed with impunity by the very agencies created and appointed to guard, defend, and enforce them.... The doctrine is not to be tolerated.

Despite discomfort with the unitary theory of the federal sovereign, the theory survived more or less intact until the later years of the nineteenth century. Increasingly, though, commentators derided the government's refusal to grant legal relief for people it injured. In the latter portion of the nineteenth and beginnings of the twentieth centuries, political scientists and others began to attack the traditional view of sovereignty. In 1893, Ernst Freund subjected the unitary doctrine to withering analysis. Freund $(1893,638)$ noted that "there are evidently cases where justice demands the adjudication of rights against the state, while the logic of the law apparently forbids it." He thought that this apparent conflict makes sense only if the state is viewed as a unitary sovereign, which he thought to be a dangerously simplistic view: "The state is an exceedingly complex organism, and its functions are widely divergent.... The concentration of these various functions in one power would be impossible without a separation of organs" (638). Freund suggested that the regulative effects of liability would act as a check on governmental activity (647-8). These effects could be especially important in the face of governmental expansion and more attenuated control of administrative departments by the president.

One of the chief rationales for sovereign immunity is found in the sovereign's supervisory responsibilities in protecting the lives and properties of its subjects. The sovereign needs to be free to act in the public good without constant legal harassment that drains public coffers and diverts resources to nonproductive work. Given the multiplicity of activities and the complexity of the federal government's interaction with its citizens and others, it is clear that oversight of activity has been a major challenge to elected officials and presidentially appointed administrators for well over a century (Bibby 1966; Calvert, McCubbins, and Weingast 1989; Carpenter 1996). In the face of growing difficul- ties in maintaining control over bureaucracy, Freund's analysis suggests that citizens could in effect regulate government policy and practice through lawsuits and money damages, discouraging administrators from undertaking misdeeds.

Others were less elegant than Freund but just as vehement, deriding sovereign immunity as an "antiquated relic" of a "barbarous and monistic rationalism" (Elliott 1925, 476) and stating that "the case against 'the discredited state' is one whose strength cannot and ought not to be underestimated" (491). These sentiments echoed John Dewey, Mary Parker Follett (1919), and other pragmatist thinkers, who saw sovereignty as "a more or less shapeless wish, except as it finds expression in organized institutions" (Dewey 1894, 43). Despite these assaults, at the dawn of the twentieth century the U.S. Government was no more accountable for the wrongful behavior of its administrators who hurt citizens than was the crown of England. In the mounting pressure to rethink sovereign immunity, the federal courts began to look favorably on actions against government officials for equitable relief. Federal officials were in theory subject to equitable action from the beginning of the Republic, but the U.S. Supreme Court extended this relief to allow for federally enforceable injunctive relief against state officials (Young, ex Parte 1908). This leniency toward equitable actions followed the English tradition exemplified in Rookes Case (1599, 210), which held that the use of administrative "discretion is a science... and not to [be used] according to [administrators'] wills and private affections." But the decision in Rookes did not concern money damages, and it is clear that this holding would not apply where the remedy is a judgment against the crown treasury.

One of the chief means, of course, of bringing the U.S. Government to account is through injunctive relief, as in the school desegregation and voting rights cases. But there are important occasions when equitable remedies are useless to secure a person's rights against the federal government. On such occasions money damages from a suit in tort may provide the only means of bringing the government and its administrators to account for their actions. Along with enforcement of criminal laws, the primary legal means for controlling behavior in our society is through the application and threat of application of monetary liability.

Because organizations tend to act in more predictable and rational ways than do people, the threat of tort liability is often an effective deterrent to undesirable behavior (Calabresi 1970; Coase 1960; Landes and Posner 1987). Administrators and officers in organizations and institutions almost universally consider potential liability in tort before undertaking policies, producing products, or engaging in activities. This comprehensive reach of tort liability is comparatively recent and tracks the growth in complexity and size of our market-based economy and the products it produces. But efforts to make the federal government accountable in the form of tort liability have repeatedly stumbled on the arcane but vigorous doctrine of sovereign immunity. Additionally, Congress's consistent unwillingness to visit the issue of federal liability except in 
specific, well-publicized cases foiled hopes of diminishing the domestic effects of sovereign immunity.

Mass compensation schemes by Congress are modern remedies, and up until the passage of the FTCA in 1946, the principal method the federal government used to handle liability claims was the "private bill" system. For most of the history of the United States, claims against the states and the federal government were not statutorily authorized but were handled through legislative committees. This process distracted legislators from their duty to work on behalf of all their constituents and often resulted in great injustice or justice delayed for years, or even decades. As one member of Congress noted in 1878, "There are just claims which have been before the Congress for half a century, and been favorably considered in one Congress by one house, and in another Congress by the other without ever having received that concurrent action in any Congress necessary to determine them" (U.S. Congress, House 1878, 2). This system also had the effect of preventing judicial oversight of administrative action that caused injury to citizens. Despite the nuisance and injustice caused by the private bill system, Congress only reluctantly took steps to abandon the institution.

\section{PRIVATE BILLS AND THE FEDERAL TORT CLAIMS ACT}

The use of private bills to compensate people injured or killed by governmental actions proved to be unwieldy, expensive, and unjust. In the first three U.S. Congresses alone, members introduced 2,317 private bills for relief (U.S. Congress, House 1848, 32). The Twenty-second, Twenty-third, and Twenty-fourth Congresses saw 8,655 private bills, with 603 passing both houses, making for a $7 \%$ success rate (32). An 1848 House report on private bills in the previous decade found that 16,573 bills were introduced in the House, 3,436 reported out of committee, with only 910 passing both houses; a 5.5\% success rate (4). In the Seventy-sixth and Seventy-seventh Congresses, about four thousand bills were introduced and 908 approved, a success rate of about $23 \%$ (U.S. Congress, House 1945, 2).

While Congress was apparently reaching more bills by the time of these later sessions, it did so at great expense in time, money, and justice. Even as early as 1838, a House report complained that "members elected to participate in the examination and discussion of national subjects have devoted their time in the adjustment of private claims" (U.S. Congress, House 1838, 1). Nearly a century later, private bills still cut deeply into legislators' time (U.S. Congress, House 1942, 9-10).

Frequently, the investigative and review committees for private bills were composed of a single member, and disagreements between members of Congress affected the passage of claims for relief. Under the private bill system, justice "awaits upon political considerations or the popularity of a Congressman or the influence of a Senator" (U.S. Congress, House 1942, 51). John Quincy Adams opined, "There ought to be no private business before Congress. [Private bills are] judicial business, and legislative assemblies ought to have nothing to do with [them]" (quoted in U.S. Congress, House 1942, 49). And a House report in 1878 declared in disgust, "No tribunal can be less fitted to examine and decide upon private claims than the Congress" (U.S. Congress, House 1878, 1).

To alleviate the private bill problem, Congress experimented with the Court of Claims, which it established in 1855 (10 Stat. 612). This court represented a hybrid solution, midway between judicial and legislative determination of compensation for victims. Congress prohibited the Court from making legal determinations about liability, and the Court could only make recommendations to Congress about compensation for victims. This allowed members of Congress to "transfer responsibility [for private bills to the Court of Claims] but still make it possible for beneficial outcomes to be attributed to individual legislators" (Hill and Williams 1993, 1012). Although Congress expanded the Court's power in 1863 , the Court was still too limited and weak to alleviate the glut of private bills. Abraham Lincoln (1862) took to berating Congress for the mess it had made in this area, saying, "It is as much the duty of Government to render prompt justice against itself in favor of citizens as it is to administer the same between private individuals." These words were eventually engraved on the Court of Claims building in Washington, D.C.

Nevertheless, the problem continued unabated until 1922, when Congress passed the Small Tort Claims Act. This act authorized the head of every federal department or establishment to "consider, ascertain, adjust and determine any claim" on account of damages to or loss of privately owned property, up to one thousand dollars, caused by the negligence of an officer or employee of the U.S. Government. This statute led to some strange and unjust results. For example, the government could be liable for the cost of a pocket watch crushed by a federal employee but not for the life of the person carrying it who was run down by a mail truck.

The explosion of federal employment during the Depression and World War II put tremendous pressure on Congress to enact an effective piece of legislation that would remove claims for governmental liability to the judiciary. After several stalled attempts in the 1930s and early 1940s, legislators in the Seventy-ninth Congress poised to pass a significant bill waiving sovereign immunity in tort. Then-Attorney General Robert Jackson recommended the FTCA for passage, saying, "The subject of tort claims against the government has long been a troublesome and vexatious matter.... The ... immunity of the Government to suit in ... torts does not seem to be warranted either as a matter of principle or as a matter of justice" (U.S. Congress, House 1945, 7). It astonishes that in passing this legislation Congress held no hearings, as the bill promised to alter substantially the duties and functioning of members of Congress and affect countless thousands of constituents. It is true that Congress held hearings in 1942 on a similar bill that failed because of preoccupation with the war, but the FTCA represents a significant change in the arrangement of power and 
duties in the federal government, and it seems odd that it should proceed so quietly.

Originally, the FTCA set out to be a "general waiver" of sovereign immunity circumscribed by various exceptions. And occasionally, courts still refer to it in that way, though, at least when the DFE is implicated, it has long ceased to fulfill that function. The shift from the FTCA's original function as a general waiver of sovereign immunity to one good only in tightly circumscribed instances makes recovery under the FTCA difficult, to say the least.

The main waiver provision of the Act is short and clear: "The United States shall be liable... [for] tort claims, in the same manner and to the same extent as a private individual under like circumstances" (sec. 2674). Section 2680, though, lists 13 exceptions to this waiver of sovereign immunity. Some of the exceptions are quite sweeping, but the tiger of the lot is found in paragraph (a). The Discretionary Function Exception protects the government against claims "based upon the exercise or performance or the failure to exercise or perform a discretionary function or duty on the part of a federal agency or an employee of the Government, whether or not the discretion involved be abused." Though Robert Jackson (1940) later maligns the Supreme Court's broad interpretation of the provision in Dalehite, the terms of the DFE are in accord with his own stated New Deal impulse to free the administrator from judicial second-guessing. In the course of the last half-century, the DFE and other exceptions in the FTCA have eclipsed Congress's intention to make the United States broadly liable for negligent or malicious policies and decisions of administrators. The waiver to immunity has become the exception and the exceptions have become the rule; the FTCA has been turned inside out.

\section{THE BIG BANG: FROM GENESIS TO EVOLUTION}

The U.S. Supreme Court has visited the DFE on only four occasions, once in 1952 (Dalehite) and three times in the seven years spanning 1984-1991 (U.S. v. Varig Airlines 1984, Berkovitz v. U.S. 1988, and U.S. v. Gaubert 1991).

In Dalehite, after the destruction of Texas City, the United States and the thousands of plaintiffs who had filed suit agreed to litigate a "test" case in federal district court. All of the parties agreed to be bound by the results of the case, and the plaintiff won considerable damages at trial. Facing damages that could aggregate to more than $\$ 200$ million (conservatively, $\$ 1.4$ billion in year 2002 dollars), the stakes on appeal were enormous. In Dalehite it became clear that the FTCA could be much more than the means for compensating victims of governmentally caused injury and death and relieving Congress of the private bills burden; it could effect change in government just as expanded tort liability had changed corporate America. This was the potential result and regulative power for which Freund had hoped. The FTCA threatened to allow rank-and-file citizens to shape the activities and policies of government and to allow greater judicial oversight of the administrative process.

The Fifth Circuit Court of Appeals, hearing the appeal en banc, reversed the judgment, holding that the actions of the government in producing and shipping the FGAN were discretionary acts and therefore came under the ambit of the DFE. The court also noted that the DFE clearly indicated Congress's desire that administrators "be free from any unwarranted judicial supervision" (Texas City Disaster 1952, 778).

The U.S. Supreme Court heard the case in 1952 and, in a five-to-three decision, affirmed the ruling of the Fifth Circuit. The Court ruled that Congress did not intend to subject the sovereign to liability for "acts of a governmental nature or function" and that uppermost in Congress's waiver of sovereign immunity were "the ordinary common-law torts" (Dalehite, 28). The Court found it "unnecessary to define... where discretion ends," since the DFE "includes determinations made by executives or administrators in establishing plans, specifications or schedules of operations" (34).

But Justice Jackson, joined by Justices Black and Frankfurter, filed a scathing dissent. Jackson started by writing that the result of such a sweeping interpretation of the DFE meant that "the Government . . . can clothe official carelessness with a public interest. Hence, one of the unanticipated consequences of the Tort Claims Act has been to throw the weight of government influence on the side of lax standards of care" (50). And as for the Solicitor General's claim that the government should not be liable because it tried to emulate standard industry practice in shipping the FGAN, Jackson likened the argument to a request for "one free disaster" for each new policy (56).

Dalehite yields the paradoxical result that the greater the harm inflicted by administrators and their policies, the more remote the chance that they will be held accountable for their wrongdoing. As Jackson complained, the maxim that "The King can do no wrong" has "merely been amended to read, "The King can do only little wrongs"" (60). Lower courts interpreted Dalehite to set up a planning-operational test for application of the DFE. Planning activities were protected, while mere operational activities, those activities carrying out the details of policies and not invested with policy discretion, were not protected. For the next 30 years, the Court let its Dalehite ruling stand undisturbed, until it perceived that lower courts were taking liberties with the decision and using the planning-operational test to expand judicial oversight of administrative actions.

By the 1980s, the Court moved to quell the view that the interpretation of the DFE "expressed in Dalehite ha[d] been eroded, if not overruled" (U.S. v. Varig Airlines 1984 [hereafter Varig], 811). In Varig, relatives of passengers who died of smoke and toxic gas inhalation aboard a Boeing 707 sued the federal government for negligent inspection and certification of the aircraft. The district court found for the plaintiffs, and the Ninth Circuit Court of Appeals affirmed. On appeal, the U.S. Supreme Court provided even broader governmental protection than that embraced by Dalehite. 
The Court, in a unanimous opinion delivered by Chief Justice Burger, explained that application of the DFE depended upon two considerations: "First, it is the nature of the conduct, rather than the status of the actor, that governs whether the discretionary function exception applies in a given case"; "Second, [the DFE] plainly was intended to encompass the discretionary acts of the Government acting in its role as a regulator of the conduct of private individuals" (813). The exception is meant to prevent "judicial 'second guessing"" of policy decisions, but only those decisions "grounded in social, economic, and political policy" (814).

Four years later, another unanimous Court read the DFE to admit liability for administrators' negligent licensing and release of a lot of live polio vaccine. In Berkovitz v. U.S. (1988 [hereafter Berkovitz]), the plaintiff took live polio vaccine manufactured as Orimune and contracted polio. The disease permanently paralyzed Berkovitz, and he pressed two claims. First, he asserted that administrators negligently licensed the vaccine without first receiving testing information as required by law. Second, he claimed that they released a noncomplying lot of vaccine against their own regulations and practices. In defense, attorneys for the United States asserted that all regulatory actions are shielded from liability by the DFE. If the Court had accepted this argument, the consequences would have been enormous, since large expanses of governmental activity would have become immune to suit and judicial review. But the Court rejected this contention, holding that the DFE "will not apply when a federal statute, regulation, or policy specifically prescribes a course of action for an employee to follow" (536). Where there is no discretion there is no immunity. After Berkovitz, lower courts began to reinstitute the planning-operational distinction they had used up to the Varig decision, but the apparent loosening of judicial construction by the U.S. Supreme Court proved to be illusory.

In U.S. v. Gaubert (1991 [hereafter Gaubert]), a federal court of appeals applied a modified planningoperational distinction and found against the government. Administrators of the Federal Home Loan Bank Board (FHLBB) exerted heavy control over a bank, pressuring majority stockholder Thomas Gaubert to remove himself from management of the bank and to post a $\$ 25$ million security interest guaranteeing the bank's solvency. The goal of the FHLBB was to force Gaubert's bank to merge with a weaker bank ( Gaubert, 319). While Gaubert ran the bank, it was financially solvent, but after he stepped down, through a series of perplexing blunders, the FHLBB caused Gaubert's bank to fail (320). Gaubert lost his $\$ 25$ million security and the value of the shares he held in the bank. The district court dismissed the case under the DFE, and the Fifth Circuit Court of Appeals affirmed most of the lower court ruling. But the Court of Appeals also held that the DFE did not immunize the government for administrative actions made after assuming control of the day-to-day operational activities of the bank. The Supreme Court reversed, stating, "It is clear that the Court of Appeals erred in holding that the exception does not reach decisions made at the operational or management level of the bank involved in this case" (325). And in reclaiming territory for the government that it presumably lost in Berkovitz, the Court noted, "A discretionary act is one that involves choice or judgment; there is nothing in that description that refers exclusively to policymaking or planning functions.... Discretionary conduct is not confined to the policy or planning level" (325).

The Court reaffirmed the Varig analysis, holding that judges must determine the following: (1) Did the complained of action or inaction admit of discretion? and (2) If it did admit of discretion, was it the kind of discretion that Congress sought to immunize from liability? But the Court also added a requirement that creates a nearly insurmountable hurdle for plaintiffs: "For a complaint to survive a motion to dismiss, it must allege facts which would support a finding that the challenged actions are not the kind of conduct that can be said to be grounded in the policy of the regulatory regime" (324-5).

This meant that henceforth the burden would be on the plaintiff to show that the decision is one not "susceptible to policy analysis" (325). In explaining what "susceptible to policy analysis" meant, the Court reiterated its phrase from Varig. Decisions are protected if they implicate "social, economic, and political" policy (Gaubert, 323; Varig, 814). Very few decisions by bureaucrats cannot be squeezed into the frame of this ruling. Gaubert appears to be part of the Court's newfound respect for sovereign immunity in general and state sovereign immunity in particular. And Gaubert, along with cases such as Seminole Tribe of Florida v. Florida (1996) and Alden v. Maine (1999), signals that the doctrine of sovereign immunity is as vigorous today as it was at the beginning of the Republic. In Gaubert, again, there were no dissents, with only Justice Scalia filing a concurring opinion.

Gaubert reemphasized the formidable nature of the DFE and gave it a scope and strength beyond what it had in the past. And the Department of Justice wishes to husband this strength; using it only where the stakes are high so that it is not overused and therefore loses potency. For example, U.S. Attorneys are required to "obtain approval from the appropriate Torts Branch Staff prior to raising the 'discretionary function exception' defense. .." (Deptartment of Justice 2001, sec. 45.220). This is the only exception to the FTCA that requires prior approval before being used and, apparently, the only defense in any circumstances that must be cleared by the Department of Justice. It is clear that the DFE is the brightest flower in the "garland of prerogatives" that surrounds the sovereign in civil matters (Francis Bacon, quoted in Pollock and Maitland [1895] $1968,517)$. But our citizens pay a steep price for the maintenance of this broad protection for governmental action.

\section{QUANTITATIVE ANALYSIS OF DFE CASES}

To understand the DFE better, this section examines 377 federal circuit courts of appeals cases where the 
DFE is invoked. These cases span the time period between the first appellate decision on the DFE, May 4, 1950, and March 7, 2001, and include all reported cases where courts ruled on assertion of the DFE or indicated in dicta how they would have ruled if they had reached that issue. Cases were selected using key word searches and other means on Lexis/Nexis and Westlaw and coded by the authors based on the nature of the issue, potential impacts, the characteristics of the plaintiff, and the successful use of the DFE. Based on these codes, assertion of the DFE succeeded $72 \%$ of the time with federal courts of appeals. Seventy-two percent of the appellate court decisions affirmed lower court rulings.

This descriptive overview of cases related to the DFE at the federal appeals courts level indicates considerable consistency. In other words, most cases are related to similar causes, the defense is successful most of the time, and lower court decisions are usually affirmed. However, this consistency reflects appeals decisions over 50 years and obscures patterns and variation over time.

\section{Growth of the Use of the DFE}

Since Dalehite, the numbers of cases brought to the federal courts of appeals have fluctuated. For the first 30 years, from 1950 to 1980, the average number of DFE cases is only two per year. The average during the period from 1980 to 2000 is 15 cases. Further, as indicated in Figure 1, there has been exponential growth in the number of cases heard, reaching a high of 27 cases in 1997. This growth tracks the increasing number of cases handled by the federal court system over the last 40 years. Civil appeals in federal appellate courts increased 10-fold between 1960 and 2000 and continue to grow (Federal Court Management Statistics 2000 Krafka, Cecil, and Lombard 1995, 3).

\section{Success of the DFE Defense}

It is logical to theorize that as the DFE's use grows, its efficacy should also increase. In addition, as discussed above, several landmark cases strengthened the DFE. For most of the period from 1950 through 1985, there are too few cases reported by the federal appeals courts to draw strong inferences. As a result, success rates range from 100 to $0 \%$, and for several years in the 1970 s, the success rate oscillates between 100 and about $50 \%$ (Figure 2). During the period from 1980 to 2000, the number of cases grows and a more accurate pattern emerges. From 1980 to 1990, the percentage successful invocations of the DFE ranges from $40 \%$ in 1982 to nearly $90 \%$ in 1985 and then decreases to $50 \%$ in 1989 . After 1990, the percentage of successful use of the DFE grows rapidly, to nearly $90 \%$ in 1992 , the year after Gaubert, and then consistently remains over $70 \%$. The average success rate of the DFE is $85 \%$ from 1991 to 2000.

We examined three specific dimensions, based on a reading and coding of each of the 377 cases, to shed ad- ditional light on the DFE. Based on the coding protocol outlined below, we found that the intercoder reliability of these dimensions conducted by the authors was $100 \%$. Issues that might have an impact on the likely successful use of the DFE include the following:

(1) The number of actual and potential plaintiffs; a measure of the potential financial liability of the federal government. Determining the number of potential plaintiffs is straightforward in the large majority of cases: (a) We add up the number of named plaintiffs in a case; and (b) we determine the number of unnamed potential plaintiffs who could sue the government for the same underlying event giving rise to the case in question. In no instance did we encounter the problem of multiple cases arising from the same event, since federal civil and appellate procedure almost always requires such cases to be merged into a single action.

(2) Whether a bureaucratic decision involving administrative discretion was minimal or substantial. This information came from the facts of the case and descriptions of the actions of government employees, and we asked (a) Did a federal employee directly participate in or undertake the actions that caused the injury? and (b) If not, was the injury so closely connected to substantial governmental regulation over the subject matter that it met the functional equivalent of direct participation?

(3) Whether the broader policy implications are minimal, moderate, or substantial. First, we asked if, in the event of a finding of liability, a supervising administrator with control over the environment in question could reasonably make changes in policy to increase safety. This is a threshold question in that if the answer is "no," then ipso facto the effects on policy of a government loss are minimal. If the threshold is met, then we asked if the policy changes would be local, regional, or national in scope. In some cases policy changes would be confined to a particular locale and so would not have moderate or substantial affect on federal governmental policy. If policy changes would be national in scope, the case gained at least a "moderate" classification. If a loss in a case would cause the government to adopt new policies at the national level and would cause major expense or substantially redefine the duties of employees, we classified the case in the "substantial" category.

Number of Actual Potential Plaintiffs. The issue of the number of actual and potential plaintiffs examines whether the federal appeals courts are making considerations of the applicability of the DFE based on the potential scope of the financial impact of liability, rather than strictly on the merits of the case. In cases where the number of people affected is very large, then the successful use of the DFE should increase. When cases are coded based on the number of people affected, in $73 \%$ of the cases between one and 10 people are affected, in $8 \%$ of the cases between 11 and 100 people are affected, and in $17 \%$ of the cases over 100 people 
Bureaucracy that Kills

June 2002

FIGURE 1. Total DFE Cases, 1950-2000

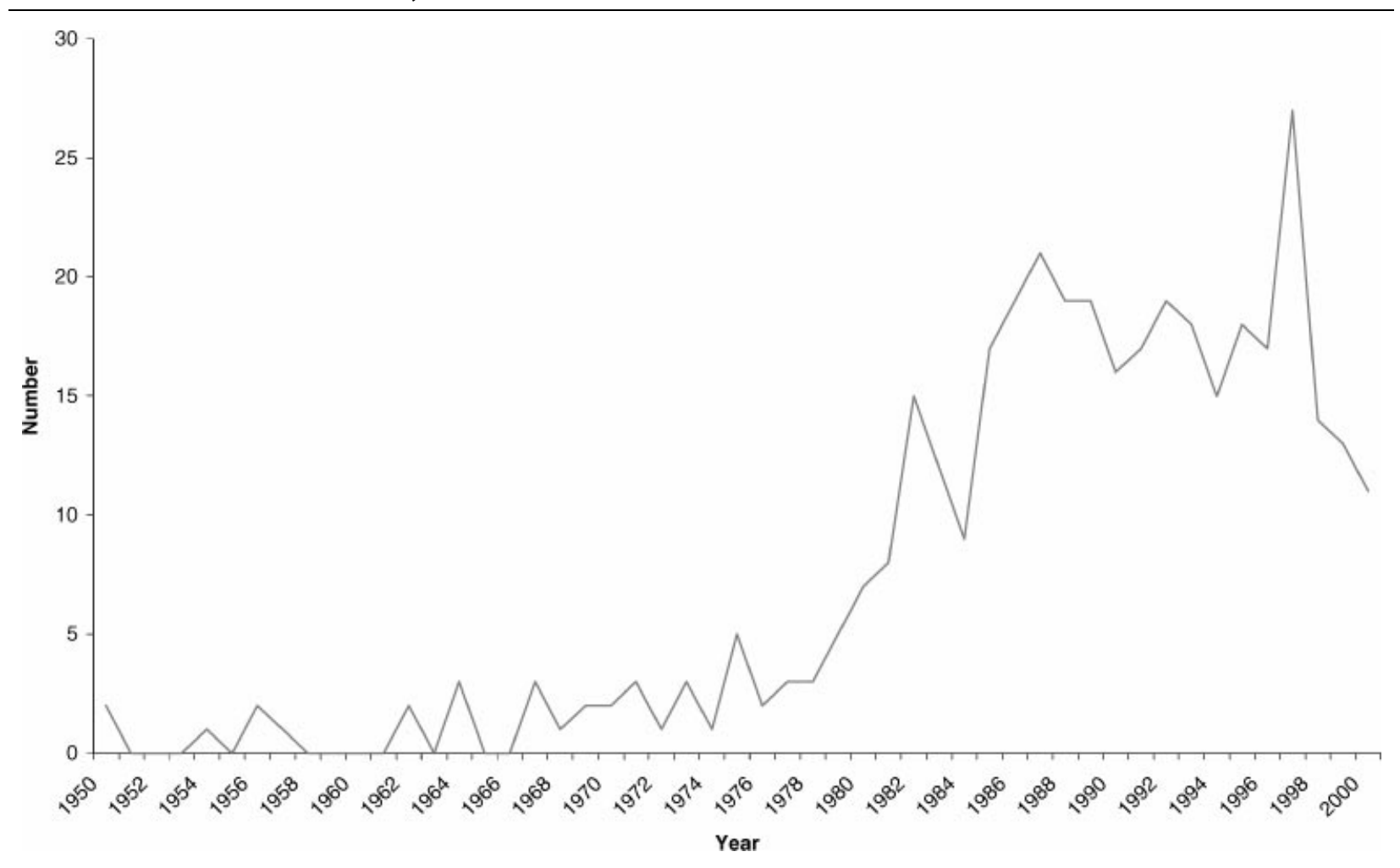

FIGURE 2. Percentage Successful Use of the DFE, 1950-2000

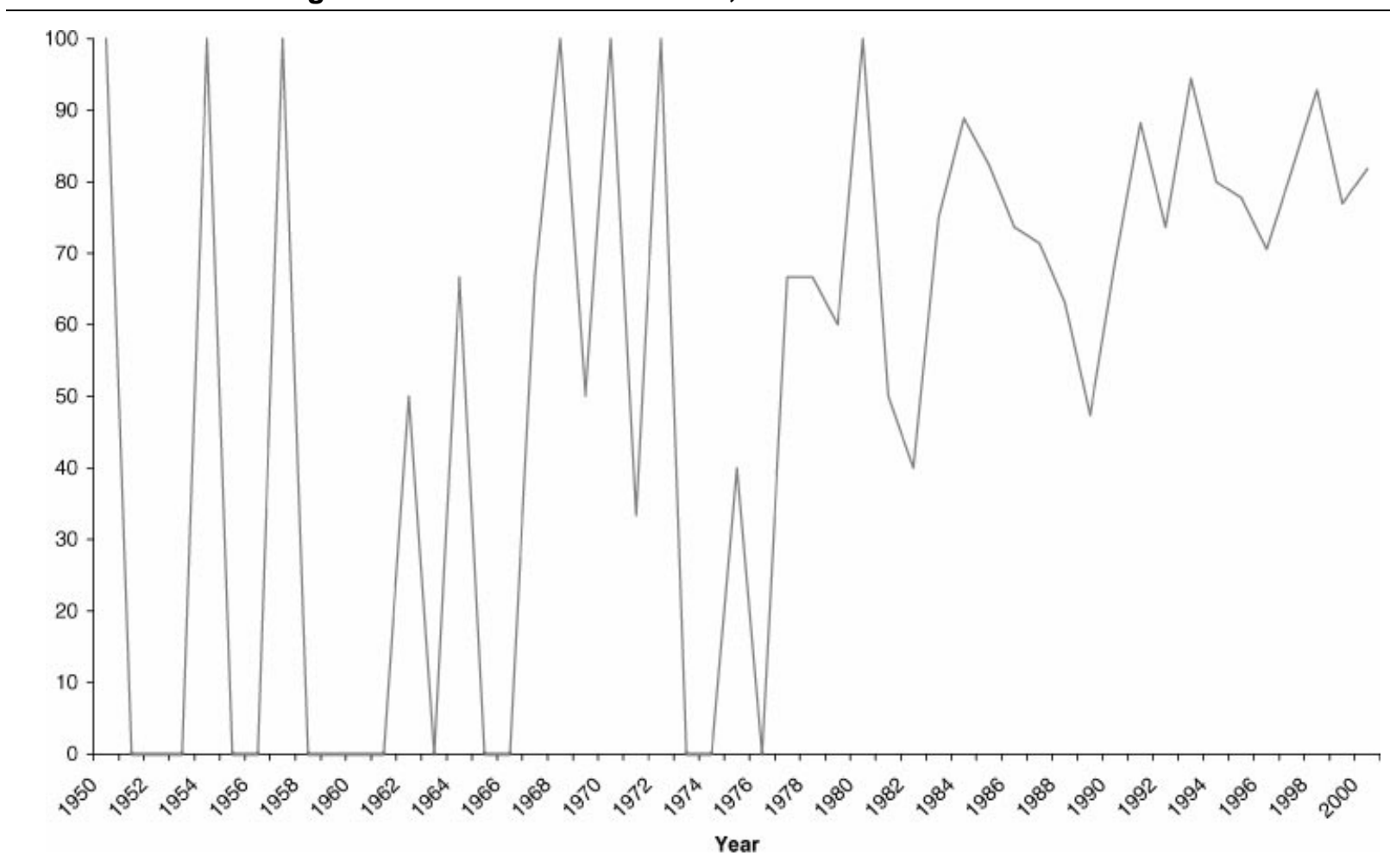

344 
are affected. While these cutoffs are somewhat arbitrary, they suggest a low, middle, and substantial scope of impact.

There is no association between the number of people affected and the successful use of the DFE $\left(\chi^{2}=1.02, p=0.602\right)$. Overall, the DFE is used successfully $72 \%$ of the time. When fewer people are affected, the success rate is slightly lower than average ( $70 \%$ for the low and $72 \%$ for the middle categories). When the number of people affected is substantial (over 100) the DFE is successful $77 \%$ of the time, but again, this difference is not large enough to reach statistical significance. We note, though, that in class action suits against the U.S. Government under the FTCA, the DFE, when raised, is successful $100 \%$ of the time.

Involvement of the Bureaucracy. Because protection of the exercise of administrative discretion is the key principle of the DFE, when there is substantial bureaucratic involvement the DFE should be more likely to succeed. Conversely, when the role of the bureaucracy is minimal, the DFE should be less likely to succeed. In $54 \%$ of the cases the level of bureaucratic involvement is minimal, and $46 \%$ of the time the level of bureaucratic involvement is substantial. There is no statistical association between the level of bureaucratic involvement and the successful use of the DFE $\left(\chi^{2}=0.293\right.$, $p=0.588)$. The DFE is successful in $73 \%$ of the cases where bureaucratic involvement is minimal and $70 \%$ of the cases where bureaucratic involvement is more substantial.

Policy Implications. When the policy implications of the case are substantial, the DFE should be more likely to succeed. In $36 \%$ of the cases, the policy implications are minimal, in $31 \%$ of the cases the policy implications are moderate, and in $33 \%$ of the cases the policy implications are substantial. There is a statistically significant association between policy implications and the successful use of the DFE $\left(\chi^{2}=16.86, p=0.000\right)$. In $65 \%$ of cases with minimal policy implications and $64 \%$ of cases with moderate policy implications the DFE is successful, compared to $85 \%$ of cases with substantial policy impact. This finding indicates that where a governmental loss in a case will work substantial changes on federal policy, the courts are substantially more likely to sustain the government's assertion of the DFE. This result stands in line with traditional New Deal principles of judicial deference to agency action. Where liability threatens "judicial sabotage" of agency independence, the judiciary is more likely to accept assertion of the DFE.

Predicting DFE Success. Logistic regression analysis is used to understand better the circumstances in which the DFE is mostly likely to be successful. The likelihood of success is examined as a function of the number of people potentially affected, the extent of involvement of the bureaucracy, and the policy consequences of the case.

When these three variables are included for all 377 cases, the model is statistically significant (model $\chi^{2}=13.55$ ). As suggested by the bivariate analysis pre- sented above, only the policy implications of the case are a statistically significant predictor of the likelihood that the DFE will be successful. The coefficient is for the number of people affected and is not in the expected direction. As the number of people affected increases, the likelihood that the government will allow itself to be sued increases (DFE not successful), however, this variable is not statistically significant. Bureaucratic involvement is in the expected direction but also is not statistically significant. Using the logistic regression to predict a "best case" for success, we find that for a case that involves many people and has substantial bureaucratic involvement and policy implications, the likelihood is that the DFE will be successful $80 \%$ of the time. The likelihood of success for the least favorable case, where many people are involved, there is little bureaucratic involvement, and there are no policy implications, is $60 \%$.

As noted above, there is a clear difference during the pre- and the post-1980 periods in terms of the number of cases per year and the likelihood of success. Using the same model to examine cases since 1980, we find that the best-case scenario for DFE success is $79 \%$, and in the worst case scenario the probability is $65 \%$. These changes in the findings indicate that the application of the DFE is basically the same for the periods before and after the growth of the DFE began in 1980 (joint log likelihood test; $\chi^{2}=6.71$, not statistically significant). The DFE is slightly more successful under the worstcase scenario (from 0.60 to 0.65 ), which shows that the federal appeals courts have broadened the scope of the DFE to cases that affect fewer people and have low policy significance and bureaucratic involvement.

The same model was also run for the cases between 1990 and 2000. This period represents relative stability in the number of cases decided each year and increasingly consistent and high support of the DFE by federal appeals courts. The period from 1990 to 2000 is statistically different from the years prior to 1990 (joint $\log$ likelihood test; $\left.\chi^{2}=13.93, p<0.05\right)$. This logistic regression is not statistically significant $\left(\chi^{2}=2.23\right.$, $p=0.526)$ and none of the case characteristics are statistically significant predictors of the outcome of the case.

\section{CONSEQUENCES OF THE DFE}

There are three types of suspect consequences created by the DFE with which we are concerned: constitutional, informational, and policy consequences. Issues of accountability are distributed among these areas in the discussion below.

\section{Constitutional Consequences}

The statutory nature of the FTCA does not mean that it does not fulfill important functions in our constitutional framework. It has, after all, largely taken over the private bill function from Congress. Even before the statutory exception to the waiver of sovereign immunity found in the DFE, the courts had provided for 
something similar through the common law and construction of constitutional principles. Indeed, statutes exposing the government to liability that do not specifically contain a discretionary function exemption have been read to contain the provision implicitly. The DFE contained in the FTCA, as it has been fleshed out by the courts, is frequently imported into cases involving the Suits in Admiralty Act (1920), the Public Vessels Act (1925), and other statutes, even though those statutes do not contain a DFE clause. The DFE is not only an exception to a waiver of sovereign immunity, but also a firewall to preserve the doctrine of separation of powers in private actions against the government. The Supreme Court reaffirms time and again that the separation of powers is a "vital check against tyranny" and a "fundamental principle[] of the Government established by the Framers of the Constitution" (Buckley v. Valeo 1976, 120-1). In the scales balanced by the Court, it is not just the arcane ancient doctrine of sovereign immunity on one side and injustice on the other. Added to the doctrine of sovereign immunity is concern for the functional integrity of our constitutional structure, and these two together, in the Court's eyes, generally outweigh the admitted injustice caused by the DFE.

But we think that the Court cuts a berth too wide of Congress and the President and ignores that the fundamental motivation behind the FTCA was to shift the burden for determining governmental liability from Congress to the judiciary. As discussed above, the main reason for this shift was to relieve Congress of the annoying and debilitating burden of private bills. But another, barely less substantial, motivation was to see that justice is done for those injured and killed by administrative negligence or malevolence. Congress itself reported that "the United States courts are well able and equipped to hear these claims and to decide them with justice" (U.S. Congress, Senate 1946, 25). Judicial deference in many DFE cases amounts, we think, to abdication by the courts of their constitutional responsibilities for oversight of Congress and the Executive and causes both unnecessary injustice and an unwise enlargement of Executive power.

\section{Depriving the Public of Information}

The DFE is a jurisdictional bar; when it operates, federal courts are without power to hear the case. So where the DFE is successful, it prevents not only trial but, much of the time, discovery. This means that there is no opportunity for the plaintiff to force production of evidence from the government. This makes the DFE a useful device to prevent the disclosure of embarrassing or politically explosive information. For example, in Consolidated Atmospheric Testing, in re (1987 [hereafter Consolidated]), the district court dismissed the case under the DFE before any discovery of government documents and witnesses could be accomplished. In this case, a large number of plaintiffs sued government contractors for illness and death due to their exposure to radiation through nuclear weapons man- ufacture and fallout from aboveground weapons tests. The fallout victims, "downwinders," as Howard Ball $(1986,197)$ concludes in an exhaustive study of the subject, were "misinformed about their safety, they were trapped in a bureaucratic operation that prevented the truth from emerging about the actual levels of radiation exposure." Congress, in what came to be known as the Warner Amendment, acted to cut off money damages remedies for these victims by making suit against the government under the FTCA the only available legal action for radiation exposure. ${ }^{2}$ This meant either that suits against contractors and other nongovernmental businesses and personnel were dismissed or that the government was substituted as the defendant.

Of course, Congress could not but anticipate that the government would prevail in these suits based on the doctrine of sovereign immunity and the DFE. In Consolidated, the Ninth Circuit Court of Appeals upheld the district court's dismissal of the suit under the DFE, and the U.S. Supreme Court denied certiorari (see, sub nomine, Konizeski v. Livermore Labs 1988). Congress's actions funneled victims into a headlong collision with the DFE, which offered little chance for recovery or even the opportunity to find the truth concerning the actions of administrators and contractors. It played out as expected, and when the Supreme Court denied certiorari it cut off legal recovery for over half a million victims and their families. ${ }^{3}$

But not only did the victims lose, but also the rest of the public. In some circumstances, discovery and trial are the most efficient means to unearth information about government practices. In this way, suit against the government complements regulatory goals of the First Amendment by providing important material showing what sorts of things the government is doing or has done in the past. Counsel who authored the unsuccessful Petition for Writ of Certiorari to the U.S. Supreme Court in Consolidated, later commented,

Had Congress permitted the suits to proceed, the plaintiffs would have been able through civil discovery to compel the production of a great deal of information about the manner in which the government and the contractors carried

\footnotetext{
${ }^{2}$ Congress adopted section 1631 of the Department of Energy National Security and Military Applications of Nuclear Energy Authorization Act of 1985, codified at 42 U.S.C. section 2212. This provision holds that an action against the United States under the FTCA shall be the exclusive remedy for injuries "due to exposure to radiation based on acts or omissions by a contractor in carrying out an atomic weapons testing program under a contract with the United States" [sec. 2212(a)(1)]. The Act applied "without regard to when the act or omission occurred" [sec. 2212(a)(2)] and to existing cases that had not culminated in a final, unreviewable judgment (see Hammond $\mathrm{v}$. U.S. 1986). A serious threat to eliminate this provision came in the summer of 1990 in debate and amendment on the National Defense Authorization Act. More than 40 senators cosponsored legislation to repeal the Warner Amendment, including Senator Warner. The legislation failed.

3 This estimate includes 220 thousand military personnel, 150 thousand civilian contract workers, and 170 thousand "downwinders" of test blasts (Congressional Record 1990, S12119). The government purposely did not warn these victims in order to facilitate longterm studies of the effects of radiation fallout (see, e.g., Lawrence Livermore National Laboratory 1984 and U.S. Deptartment of Energy 1995, 24-30).
} 
out the atomic tests, about the numbers and identities of exposed veterans, [and] about what the contractors and the government knew of the hazards of radiation at the time of the tests.... (Fletcher 1990, 308-9)

Although many in Congress were ambivalent about the disclosure of atomic testing information, a few members were decidedly against any disclosure. Senator Pete Domenici, for example, in arguing against a popular, though ultimately unsuccessful, effort to repeal the Warner Amendment, said that "lawyers ... are kind of itching, just salivating [about suing the U.S. Government in radiation exposure cases]" and are acting not out of interest for their clients or even for money, "but to get their hands on the documents that are in the national laboratories so they can expose the American people what $[\mathrm{sic}]$ went on the past 50 years" (Congressional Record 1990, S12119).

It is difficult to see what damage disclosure of documents in this area would have had except for embarrassment. Most of these documents have now been released, and many thousands are available on the Web through government servers. These disclosures, though controversial, had salutary effects on our society and government. Senator Domenici and those who worked to defeat the repeal of the Warner Amendment were nearsighted. Embarrassment at disclosure is also a means of accountability, a way of controlling administrative behavior, and courts flatly reject potential embarrassment as a basis for prior restraint or criminal prosecution in the disclosure of government documents. As Justice Douglas noted, "The dominant purpose of the First Amendment was to prohibit the widespread practice of governmental suppression of embarrassing information" (New York Times Co.v. U.S. 1971, 723-4).

Unless an injured party, especially after Gaubert, already has facts in hand to show that a policy violation occurred or that the decision was not discretionary, he or she will frequently not have the opportunity to force government production of evidence pertinent to the case.

\section{Policy and Directive Formulation}

Government attorneys and policymakers know that liability will arise when an agent of the government violates a specific and clear directive. As discussed in Berkovitz, the government's negligent release of a vaccine lot that failed to conform to specified standards drew liability. This standard for recovery in some circumstances gives no incentive for administrators and policymakers to develop policies and directives aimed at protecting the public. Administrators can simply opt to write no standards or specific directives in those situations where that is possible. As a circuit court of appeals in a recent case found, "The random and uncodified practices of a local supervisor cannot create the kind of specific obligation that gives rise to liability" (Irving v. U.S. 1998, 168). This finding, and others like it, encourages administrators to adopt vague policies.
The public policy goals of tort law are predicated on a number of effects that liability has on actors. Among these is the aim of increased safety by visiting liability on people best positioned to cause changes in policy and practice. But the DFE preempts these effects, and poor policies, or policies that cause avoidable dangers, go unexposed and unchanged; "[a] predicament ... at odds with the FTCA's promise to treat the government like a 'private person' for purposes of tort liability" (Levine 2000, 1542). We do not rule out the possibility that agencies will change their behavior because of attempted yet unsuccessful litigation. But the high success rate of the DFE and the extremely small chance that any suit will be successful provide little impetus for administrators to revisit policies after unsuccessful suits.

Additionally, administrators engage in two practices that further immunize agencies and personnel from accountability. The first of these is founded upon statutes that allow for the United States to substitute itself for named defendants in certain circumstances. The Westfall Act (1988, sec. 2679(d)(1)) allows the government to substitute itself as defendant for a federal worker when the Attorney General certifies that the worker was acting within the scope of his or her employment when the injury occurred. Once the government is substituted as defendant, the problem is shifted from the employee and agency in question to the Department of Justice. The offending employee and his or her agency are not made to internalize the costs of their actions.

The second practice that insulates administrators from accountability is found in the way the United States pays out judgments when it does lose to a plaintiff. Even if a plaintiff is successful in suit against the government or negotiates a settlement, judgments larger than specified dollar amounts for each agency are paid out of a judgment fund maintained by the Department of the Treasury's Financial Management Service (FMS) (1998, 1999). For example, judgments in excess of $\$ 25$ thousand against the FBI are referred to the FMS for payment. Further, any judgments paid from the fund do not come out of the offending agency's budget. Thus there is no incentive for administrators to reevaluate policies and procedures in the wake of liability, since they do not have to provide the legal resources to defend their agencies or pay judgments. Former Attorney General Reno (1997) remarked, "I came to Washington to discover that a client agency oftentimes has a judgment paid out of a judgment fund rather than its regular appropriation. It doesn't hurt. So there's not that much of an incentive. Let the Justice Department worry about it."

The Department of Justice Torts Division has become adept at handling problems not its own, injuries it did not inflict. It draws accountability away from offending agencies and flawed or even malicious policies, thus alleviating the need to evaluate those policies in light of the injuries they cause to citizens. Increased success of the DFE, coupled with the Westfall Act and the operation of the judgment fund, leads to precisely the sort of unchecked discretion that thinkers reacting to New Deal administrative theory feared most. 


\section{CONCLUSION}

There are often good reasons and uses for the retention of sovereign immunity, even when administrators act negligently or intentionally in harming citizens. But this retention of immunity should be carefully circumscribed so that the beneficial functions of making the government vulnerable to suit are not undermined. Administrators, though, most vigorously assert immunity where the damage imposed on society is greatest. This means that often neither the oversight function of administrative action transferred by Congress to the judiciary in the FTCA nor the ameliorative effects of liability will reach government administrators. By admission of the Chief of the Torts Branch, Department of Justice (Axelrad 2001), when government caused injuries are far reaching, as in the class action suits of Consolidated Atmospheric Testing, in re (1987) and Agent Orange, in $r e$ (1987), the DFE is the primary means for preventing liability or discovery. Indeed, the United States won in all eight reported federal courts of appeals cases in which it raised the DFE to protect itself against class actions.

With such a successful tool available, the temptation to use it is understandably strong, and this substantially affects our constitutional system and governmental accountability. In giving too much deference to the separation of powers and the doctrine of sovereign immunity, the federal judiciary created an environment that sometimes does not encourage administrators to use care or to abandon unnecessarily injurious policies. The DFE is an anachronism, a living remnant of New Deal faith in the expert agency that must be free of judicial sabotage. Although the effectiveness and advisability of comprehensive judicial oversight of administrative agencies are a contentious issue, in the case of the FTCA and the DFE many of the standard reasons for deferring to administrative discretion are less convincing than in other circumstances. In the context of the DFE, judges do not order agencies to forgo or modify policies, nor do they substitute their judgment for that of the administrator. Considering the operation of the judgment fund, one cannot even say that imposition of liability is the functional equivalent of replacement of agency expertise by judge-made predilection. No doubt liability does prompt policy changes, but it is unpersuasive to claim that administrators who do not feel the sting of monetary damages under the FTCA are nevertheless under judicial coercion to change or modify policies causing injury.

Reinterpreting the DFE narrowly and expanding judicial power to influence agency policies and practices could expose agencies to greater public scrutiny. Information made public through legal action may also provide impetus and guidance for congressional efforts at agency oversight. As Raoul Berger testified, Congress cannot perform its duty to investigate agencies "from hell to breakfast" (U.S. Congress, House 1972, 3132) without information "as to what is going on in the subterranean depths of the executive branch" (3116). Sometimes one of the best ways of plumbing those "subterranean depths" is by means of a suit in tort.
Above all, we cannot forget the interests of the deserving plaintiffs who nonetheless are cut off from justice by operation of the DFE. Lawrence Friedman $(1985,43)$, in his book Total Justice, claims that "general expectations" of recompense and justice have become "superprinciples" in our society. It would be difficult, though, to find a more severe violation of "total justice" than the DFE, and it thwarts Friedman's "superprinciples" with astonishing frequency.

\section{REFERENCES}

Agent Orange, in re. 1987. 818 F.2d 194 (2nd Cir.).

Alden v. Maine. 1999. 527 U.S. 706.

Allen v. U.S. 1987.816 F.2d 1417 (10th Cir.).

Atomic Energy Commission. 1953. Proceedings of Project Sunshine Conference, 21-23 July 1953. U.S. Department of Energy Accession No. NV0027655.

Atomic Energy Commission. Division of Biology and Medicine. 1955. Proceedings of the Biophysics Conference, 18 January 1955. Document No. 0727441. <http://hrex.dis.anl.gov/> (January 8, 2002).

Axelrad, Jeffrey. 2000. Telephonic interview. 21 November.

Ball, Howard. 1986. Justice Downwind: America's Atomic Testing Program in the 1950s. New York: Oxford University Press.

Berkovitz v. U.S. 1988. 486 U.S. 531.

Bibby, John F. 1966. "Committee Characteristics and Legislative Oversight of Administration." Midwest Journal of Political Science 10 (February): 78-98.

Blachly, Frederick F., and Miriam E. Oatman. 1946. "Sabotage of the Administrative Process." Public Administration Review 6 (Summer): 213-22.

Buckley v. Valeo. 1976. 424 U.S. 1.

Calabresi, Guido. 1970. The Cost of Accidents: A Legal and Economic Analysis. New Haven, CT: Yale University Press.

Calvert, Randall L., Mathew D. McCubbins, and Barry R. Weingast. 1989. "A Theory of Political Control and Agency Discretion." American Journal of Political Science 33 (August): 588-611.

Carpenter, Daniel P. 1996. “Adaptive Signal Processing, Hierarchy, and Budgetary Control in Federal Regulation." American Political Science Review 90 (June): 283-302.

Chisholm v. Georgia. 1793. 2 Dall. 419.

Coase, Ronald H. 1960. "The Problem of Social Cost." Journal of Law and Economics 3 (October): 1-44.

Cohens v. Virginia. 1821. 6 Wheat. 264.

Congressional Record. 1990.101st Cong., 2d sess., vol. 136, S12115-02. Consolidated Atmospheric Testing, in re. 1987. 820 F. 2d 982 (9th Cir.). Dalehite v. U.S. 1952. 346 U.S. 15.

Davis, Kenneth Culp. 1969. Discretionary Justice: A Preliminary Inquiry. Baton Rouge: Louisiana State University Press.

Debates and Proceedings in the Congress of the United States. 1965. Princeton: Princeton Microfilm Corporation.

Department of Justice. 2001. U.S. Attorney's Manual. Washington, DC: Department of Justice.

Department of the Treasury. Financial Management Service. 1998. Treasury Annual Report: Fiscal Year 1998. Washington, DC: Department of the Treasury.

Department of the Treasury. Financial Management Service. 1999. Treasury Annual Report: Fiscal Year 1999. Washington, DC: Department of the Treasury.

Dewey, John. 1894. "Austin's Theory of Sovereignty." Political Science Quarterly 9 (March): 31-52.

Ehrlich, J. W. 1959. Ehrlich's Blackstone. San Carlos, CA: Nourse.

Elliott, W. Y. 1925. "Sovereign State or Sovereign Group." American Political Science Review 19 (August): 475-99.

Evans, Alona E. 1980. "Sami v. United States." American Journal of International Law 74 (October): 949-52.

Falk, Richard A. 1965. "The Shimoda Case: A Legal Appraisal of the Atomic Attacks upon Hiroshima and Nagasaki." American Journal of International Law 59 (October): 759-93.

Feather v. Queen. 1865. 122 Eng. Rep. 1191. 
Federal Court Management Statistics. 2000. <http://www.uscourts. gov/fcmstat/index.html $>$ (January 5, 2002).

Federal Tort Claims Act. 1946. United States Code. Title 28, secs. 2671-80.

Fletcher, William. 1990. "Atomic Bomb Testing and the Warner Amendment: A Violation of the Separation of Powers." Washington Law Review 65 (April): 285-321.

Follett, Mary Parker. 1919. "Community Is Process." Philosophical Review 28 (November): 576-88.

Freund, Ernst. 1893. "Private Claims against the State." Political Science Quarterly 8 (December): 625-52.

Friedman, Lawrence M. 1985. Total Justice. New York: Sage.

Friendly, Henry J. 1962. The Federal Administrative Agencies. Cambridge, MA: Harvard University Press.

Frigard v. U.S. 1988. 862 F.2d 201 (9th Cir.).

Gellhorn, Walter, and Clark Byse. 1974. Administrative Law. Mineola, NY: Foundation Press.

Hammond v. U.S. 1986. 786 F.2d 8 (1st Cir.).

Hill, Jeffrey S., and Kenneth C. Williams. 1993. "The Decline of Private Bills: Resource Allocations, Credit Claiming, and the Decision to Delegate." American Journal of Political Science 37 (November): 1008-31.

Irving v. U.S. 1998.162 F.3d 154 (1st Cir.).

Jackson, Robert. 1940. "The Administrative Process." Journal of Social Philosophy 5 (January): 143-49.

Jaffe, Louis L. 1951. "Judicial Review: 'Substantial Evidence on the Whole Record."' Harvard Law Review 64 (June): 1233-61.

Jaffe, Louis L. 1963. "Suits Against Governments and Officers: Sovereign Immunity." Harvard Law Review 77 (November): $1-39$.

Jaffe, Louis L. 1965. Judicial Control of Administrative Action. Boston: Little, Brown.

Jaffe, Louis L. 1973. "The Illusion of the Ideal Administration." Harvard Law Review 86 (May): 1183-99.

Jet Industries, Inc. v. U.S. 1985. 777 F.2d 303 (5th Cir.).

Kawananakoa v. Polyblank. 1907. 205 U.S. 349.

Konizeski v. Livermore Labs. 1988. 485 U.S. 905.

Krafka, Carol, Koe Cecil, and Patricia Lombard. 1995. "Stalking the Increase in the Rate of Federal Civil Appeals." Washington, DC: Federal Judicial Center.

Krent, Harold J. 1997. "Reviewing Agency Action for Inconsistency with Prior Rules and Regulations." Chicago-Kent Law Review 72: $1187-1252$

Landes, William M., and Richard A. Posner. 1987. The Economic Structure of Tort Law. Cambridge, MA: Harvard University Press.

Lawrence Livermore National Laboratory. 1984. "Risk of Developing Lung Cancer Following Dose of 0.45 Rad." 13 September. Document No. 0717813. <http://hrex.dis.anl.gov/> (January 5, 2002).

Leigh, Monroe. 1987. “Gerritsen v. De La Madrid.” American Journal of International Law 8 (October): 947-49.

Levine, James R. 2000. "The Federal Tort Claims Act: A Proposal for Institutional Reform." Columbia Law Review 100 (October): 1538-71.

Lincoln, Abraham. 1862. Congressional Globe, 37th Cong., 2d sess., app. 1-4.

Madison, James, Alexander Hamilton, and John Jay. [1788] 1961. The Federalist Papers. Ed. Clinton Rossiter. New York: New American Library.

Marbury v. Madison. 1803. 1 Cranch 137.

McCullough v. Maryland. 1819. 4 Wheat. 316.

Minns v. U.S. 1998. 155 F.3d 445 (4th Cir.).

New York Times Co. v. U.S. 1971. 403 U.S. 713.
Nevin v. U.S. 1983. 696 F.2d 1229 (9th Cir.).

Philadelphia Enquirer. 1995. "Researchers 'Snatched' Bodies for Secret Testing." July 18, A2.

Poindexter v. Greenhow. 1885.114 U.S. 270.

Pollock, Frederick, and Frederic Maitland. [1895] 1968. The History of English Law. 2nd ed. Cambridge: Cambridge University Press.

Public Vessels Act. 1925. Title 46, secs. 781-90.

Rand Corporation. 1953. "World-Wide Effects of Atomic Weapons: Project Sunshine." 6 August. Document No. 0717541. <http://hrex. dis.anl.gov/> (8 January 2002).

Reno, Janet. 1997. Speech. San Antonio, TX. 30 January. Transc. by Marsha Yarberry.

Roche, John P. 1961. "The Founding Fathers: A Reform Caucus in Action." American Political Science Review 55 (December): 799816.

Rookes Case. 1599. 77 Eng. Rep. 209.

Rosenberg, Gerald N. 1991. The Hollow Hope: Can Courts Bring about Social Change? Chicago: University of Chicago Press.

Rosenbloom, David H. 2001. "Whose Bureaucracy Is This, Anyway? Congress' 1946 Answer." PS: Political Science and Politics 35 (December): 773-77.

Seminole Tribe of Florida v. Florida. 1996. 517 U.S. 44.

Semmelman, Jacques. 1993. "Industria Panificadora, S.A. v. United States: U.S. Court of Appeals, D.C.: Goldstar (Panama) S.A. v. United States." American Journal of International Law 87 (April): 288-92.

Small Tort Claims Act. 1922. United States Code. Title 31, secs. 21517.

Suits in Admiralty Act. 1920. United States Code. Title 46, secs. 74152.

Taitt v. U.S. 1983. Civil Action No. 82-M-1731 (Dist. of Colorado).

Texas City Disaster, in re. 1952. 197 F.2d 771 (5th Cir.).

U.S. Congress. House. Committee on Claims. 1838. Board of Claims. 25th Cong., 2d sess., H. Rept. 730.

U.S. Congress. House. Committee of Claims. 1848. Claims against the United States. 30th Cong., 1st sess., H. Rept. 498.

U.S. Congress. House. Committee on Government Operations. 1972. U.S. Government Information Policies and Practices-Problems of Congress in Obtaining Information from the Executive Branch. Part 8. 92nd Cong., 2nd sess. 23 May.

U.S. Congress. House. Committee on the Judiciary. 1942. Tort Claims. 77th Cong., 1st sess., 29 January.

U.S. Congress. House. Committee on the Judiciary. 1945. Tort Claims against the United States. 79th Cong., 1st sess., H. Rept. 1287.

U.S. Congress. House. Committee on Reform in the Civil Service. 1878. Private Claims against the Government. 45th Cong., $2 \mathrm{~d}$ sess., H. Rept. 812.

U.S. Congress. Senate. Joint Committee on the Organization of Congress. 1946. Organization of the Congress. 79th Cong., 2nd sess., S. Rept. 1011.

U.S. Department of Energy. 1995. "Human Radiation Studies: Remembering the Early Years, Oral History of Health Physicist Karl Z Morgan, Ph.D.” January 7. Document No. 0727855. $<$ http://hrex.dis.anl.gov/> (January 5, 2002).

U.S. v. Gaubert. 1991. 499 U.S. 315.

U.S. v. Varig Airlines. 1984. 467 U.S. 797.

Waldo, Dwight. 1948. The Administrative State: A Study of the Political Theory of American Public Administration. New York: Ronald Press.

Welsome, Eileen. 1999. The Plutonium Files. New York: Dial Press. Westfall Act. 1988. Title 28, sec. 2679.

Young, ex Parte. 1908. 209 U.S. 123. 